\title{
Effects of Some Environmental Factors on Milking Time Milk Yield in Red Holstein Cows
}

\section{Atakan Koç* A R T I C LE I N F O \\ Research Article \\ Received 22 March 2017 \\ Accepted 12 May 2017}

Department of Animal Science, Faculty of Agriculture, Adnan Menderes University, 09100 Aydin, Turkey

Keywords:

Milking time

Calving month

Peak milk yield

Heat stress \begin{abstract}
A B S T R A C T
The purpose of this study is to investigate the environmental factors on the milking time milk yield of Red Holstein cows. For this aim, 172,826 morning milk yield (MMY) and 172,771 evening milk yield (EMY) data collected between 2001 and 2010 from a dairy farm in Aydin Province, Turkey were used. The THI is over 72 from June to August in the region. The effects of calving month, calving year, parity, lactation month and milking month on MMY and EMY were found to be statistically significant $(\mathrm{P}<0.01)$. For every month, year and parity, the MMY means were higher than those of the EMY. The peak daily milk yield was determined on the $46^{\text {th }}$ day of lactation $(31.7 \pm 0.013 \mathrm{~kg})$. For parity, the highest milk yield means were detected for the third parity: $13.69 \pm 0.023 \mathrm{~kg}$ for MMY and $11.70 \pm 0.021 \mathrm{~kg}$ for EMY. In conclusion, taking precautions to protect the cows from heat stress especially for the cows calved in summer and keeping the milking interval equal for whole year would help increasing the milk yield.
\end{abstract}

\footnotetext{
*Corresponding Author:

E-mail: akoc@adu.edu.tr
}

DOI: https://doi.org/10.24925/turjaf.v5i8.917-922.1240

\section{Introduction}

The milk yield of a dairy cow is affected by genetic capacity of it and some environmental factors. Feeding programs, herd management, health and climatic factors are the main environmental factors affecting the milk yield. In a hot environment, climatic factors, temperature, humidity, wind velocity, solar radiation is the main factors that affect animal comfort.

Heat stress is one of the main factors affecting the comfort of the cow. It depends on the breed and body temperature regulation changes under heat stress in a hot environment (Hammond et al., 1998). When a dairy cow cannot maintain its body temperature within a physiological range, thermal stress occurs and thus respiration rate, body temperature, drinking frequency and water intake increases and also feed intake, milk yield, milk constituents, health condition, mobility and also fertility of it decreases. Under thermo-neutral environmental conditions, animals can maintain physiological parameters in equilibrium and keep their body temperature constant. Maintaining the physiologic parameters of animals in a narrow range can compromise thermoregulation (Banerjee and Ashutosh, 2011).

To determine heat stress in cattle, the temperaturehumidity index (THI) is used and THI of 72 is accepted as a threshold for heat stress in dairy cows (Ravagnolo and Misztal, 2000; Gantner et al., 2011). However, some researchers indicated that heat stress starts below this level (Linvill and Pardue, 1992). Under heat stress conditions, production costs increase in dairy industry (Gantner et al., 2011), and the milk yield, fat and protein contents decrease (Ravagnolo and Misztal, 2000; Barash et al., 2001; Bernabucci et al., 2002; Gantner et al., 2011). Somatic cell count in milk of dairy cow can also be increased under heat stress conditions (Bouraoui et al., 2002; Bertocchi et al., 2014).

In hot summer months, there can be significant decreases in milk yield in Red Holstein (RH) (Koc, 2012; 2015), in fat content in Holstein and Montbeliarde cows (Koc, 2011), in protein content in RH (Koc, 2011; 2015), in non-fat dry matter content in bulk milk in Holstein, Montbeliarde and RH cows (Koc, 2008; 2011; 2015) as well as increases in somatic cell count in bulk milk in RH, Holstein and Montbeliarde cows (Koc, 2008; 2011, Yilmaz and Koc, 2013).

Some studies reported significant milking time effects on milk yield as well as milk constituents of dairy cows (Koc and Kizilkaya, 2009; Koc, 2007; 2015; Yilmaz and Koc, 2013). It was reported that morning milk yield in Holstein (Koc and Kizilkaya, 2009) and in Red-Holstein (Yimaz and Koc, 2013; Koc 2015) is higher than that of evening milk yield. Depending on the decrease in evening milk yield, solid component of milk would be increases and protein content in evening milk yield of Red-Holstein cows was reported higher than that of morning milk yield (Koc, 2015). 
The objective of this study was to determine the effects of some environmental factors on milking time milk yield in Red Holstein cows raised under Mediterranean climatic conditions in Aydin Province, Turkey.

\section{Materials and Methods}

The Red Holstein data was collected between 2001 and 2010 from the farmer's records. The farm is located in Aydin Province, Turkey and has Mediterranean climate. The geographic coordinates of the farm are $37^{\circ}$ $45^{\prime} 48.15^{\prime \prime} \mathrm{N}$ and $27^{\circ} 17^{\prime} 34.45^{\prime \prime} \mathrm{E}$. In order to evaluate the climate in the region and monitor the heat stress in cows on the farm, the long term monthly averages of temperature $\left({ }^{\circ} \mathrm{C}\right)$ and relative humidity (\%) of Aydin province obtained from the Turkish State Meteorological Services (2012) were used to calculate THI from the formula developed by Kibler (1964). As seen in Figure 1a, the long-term monthly average highest temperature and $\mathrm{THI}$ for the region are $33.5^{\circ} \mathrm{C}$ and 72.97 in June, $36.1^{\circ} \mathrm{C}$ and 76.15 in July, $35.4^{\circ} \mathrm{C}$ and 75.49 in August and $32.0^{\circ} \mathrm{C}$ and 70.26 in September, respectively. The average calving interval, lactation length, lactation milk yield, and $305-\mathrm{d}$ milk yield of this $\mathrm{RH}$ herd were $443 \pm 4.9 \mathrm{~d}$, $349 \pm 4.0 \mathrm{~d}, \quad 8.509 \pm 120.1 \mathrm{~kg}$, and $7.679 \pm 87.5 \mathrm{~kg}$, respectively (Koc, 2012).

The cows in this herd milked twice in a day, roughly 12 hours apart, but the milking interval could be 11-13 hours depending on the length of the day. The cows were kept in an open stall barn and were cooled with fans in summer. For statistical analysis, 172.826 morning milk yield (MMY) data and 172.771 evening milk yield (EMY) data belonging to 431 lactations of 169 cows were used. The MMY and EMY data were analyzed separately. Lactations were defined as starting one day after calving, and due to colostrum production at the first few days, the milk yield of these days were estimated with the averages of the first three days records of the cows for that lactation. During lactation, missing records were estimated as the averages from the last three and the next three days records. If the number of missing records were more than 15 days, then interpolation was not done and that lactation was not included in the analysis. For the long lasting lactation, only the records of the first 550 days were used.

Before the statistical analysis, twelve calving months (1,2, and 12), ten calving years (from 2001 to 2010), five parity classes (1, 2, 3, 4, and 5 or more), twelve lactation months $(1,2, \ldots$ and 12 or more) and twelve milking months $(1,2, \ldots$ and 12$)$ were assumed. Data were analyzed using the GLM procedure in SAS (1999). The differences between the least squares means of fixed factor levels were considered to be statistically significant at $\mathrm{P}<0.05$ (2-tailed) based on Tukey's adjustment type-I error rate. The statistical model used for the analysis was as follows:

$$
\mathrm{y}_{\mathrm{ijklmn}}=\mu+\mathrm{a}_{\mathrm{i}}+\mathrm{b}_{\mathrm{j}}+\mathrm{c}_{\mathrm{k}}+\mathrm{d}_{\mathrm{l}}+\mathrm{f}_{\mathrm{m}}+(\mathrm{ad})_{\mathrm{il}}+(\mathrm{df})_{\mathrm{lm}}+\mathrm{e}_{\mathrm{ijklmn}}
$$

Where, $y_{\mathrm{ijklmn}}$ is morning or evening daily milk yield, $\mu$ is overall mean, $a_{i}$ is the calving month effects $(i=1,2$, $3, \ldots$ and 12$), b_{j}$ is the calving year effects $(j=2001$, $2002, \ldots$ and 2010$), \mathrm{c}_{\mathrm{k}}$ is the parity effects $(\mathrm{k}=1,2,3,4$ and $5+), d_{1}$ is the lactation month effects $(1=1,2,3, \ldots$ and 12$), f_{m}$ is the milking month effects $(m=1,2,3$, ... and 12$),(\mathrm{ad})_{\mathrm{il}}$ is the calving month $\mathrm{x}$ the lactation month interaction effects, $(\mathrm{df})_{\mathrm{lm}}$ is the lactation month $\mathrm{x}$ the milking month interaction effects, and $\mathrm{e}_{\mathrm{ijklmn}}$ is normally distributed random error with mean zero and unknown variance $\sigma^{2}$.

\section{Results and Discussion}

MMY and EMY LS means in RH cows are given in Table 1. Monthly changes of THI, MMY and EMY for calving months are given in Figure 1a. The averages of MMY and EMY were $12.79 \pm 0.011 \mathrm{~kg}$ and $11.14 \pm 0.010$ $\mathrm{kg}$, respectively. Figure 1a shows that for every calving month, the MMY is higher than the EMY. In both milking times, the highest mean was determined for the April calving month (Table 1, Figure 1a) and MMY average $(14.16 \pm 0.057 \mathrm{~kg})$ was $2.14 \mathrm{~kg}$ higher than the EMY $(12.02 \pm 0.051 \mathrm{~kg})$ for this month. The lowest milk yield was seen in July for both milkings, and the means for July were $11.86 \pm 0.057 \mathrm{~kg}$ and $10.04 \pm 0.049 \mathrm{~kg}$ for MMY and EMY, respectively.

As seen in Figure 1a, for both milkings, the milk yield means dropped from April to June and then increased through October. Cows giving birth in April had $2.3 \mathrm{~kg}$ and $1.98 \mathrm{~kg}$ higher milk yield in morning and evening milkings than those who gave birth in July, respectively. These differences between the means for both milkings were also found to be statistically significant $(\mathrm{P}<0.01)$. The increases from July to October are $1.92 \mathrm{~kg}$ and 1.76 $\mathrm{kg}$ for morning and evening milkings, respectively. The decreases in milk yields in the summer calving cows might be due to the hot weather. Because the beginning of the lactations of these cows coincides with hot summer months, and seen in Figure 1a the THI of the region is over 72 at this time of the year and due to possible heat stress cows produced less milk. This has been also shown in the literature (Gurses and Bayraktar, 2012; M'hamdi et al., 2012; Sahin and Ulutas, 2011).

The mean MMY is higher than that of EMY for Holstein (Koc and Kizilkaya, 2009), Holstein and Montbeliarde (Koc, 2011) and RH (Koc, 2015; Yilmaz and Koc, 2013). For EMY, the mean found in this study is higher than the findings of Koc and Kizilkaya (2009). In this study, higher milk yield found in MMY than EMYespecially in winter-might be attributed to unequal milking interval. During the visit to the farm, the longer winter nights implied that cows were often milked late in the morning and early in the evening. However, in the summer, the interval was nearly equal. In the winter, cows produce more milk in the morning milking due to longer intervals from evening milking to morning milking. Similar to this study, Holsteins (Koc and Kizilkaya, 2009) and RH (Yilmaz and Koc, 2013; Koc, 2015) were shown to have higher milk yield in the morning milking than the evening milking. 
Table 1 LS MEANS and standard errors of morning and evening milk yield in Red Holstein cows

\begin{tabular}{|c|c|c|c|c|}
\hline \multirow{2}{*}{ Factors } & \multicolumn{2}{|c|}{ Morning Milking Milk Yield, Kg } & \multicolumn{2}{|c|}{ Evening Milking Milk Yield, Kg } \\
\hline & $\mathrm{n}$ & $\mathrm{X} \pm \mathrm{Sx}$ & $\mathrm{n}$ & $\mathrm{X} \pm \mathrm{Sx}$ \\
\hline Calving Month & & $* *$ & & $* *$ \\
\hline 1 & 21050 & $12.822 \pm 0.0519^{\mathrm{Ada}}$ & 21021 & $11.234 \pm 0.0456^{\mathrm{Aab}}$ \\
\hline 2 & 27275 & $12.759 \pm 0.0516^{\mathrm{Aa}}$ & 27267 & $11.245 \pm 0.0454^{\mathrm{AFag}}$ \\
\hline 3 & 19414 & $13.200 \pm 0.0522^{\mathrm{Bbg}}$ & 19403 & $11.370 \pm 0.0462^{\mathrm{AFbh}}$ \\
\hline 4 & 9067 & $14.156 \pm 0.0566^{\mathrm{Cc}}$ & 9074 & $12.017 \pm 0.0509^{\mathrm{Bc}}$ \\
\hline 5 & 12183 & $13.108 \pm 0.0537^{\mathrm{BDbg}}$ & 12294 & $11.286 \pm 0.0489^{\mathrm{AFabh}}$ \\
\hline 6 & 8891 & $11.977 \pm 0.0586^{\text {Ede }}$ & 8860 & $10.334 \pm 0.0528^{\mathrm{Cd}}$ \\
\hline 7 & 14972 & $11.862 \pm 0.0566^{\mathrm{Ed}}$ & 14614 & $10.040 \pm 0.0488^{\mathrm{De}}$ \\
\hline 8 & 12892 & $12.043 \pm 0.0569^{\mathrm{Ee}}$ & 12907 & $10.099 \pm 0.0480^{\mathrm{De}}$ \\
\hline 9 & 18032 & $12.821 \pm 0.0564^{\mathrm{Ada}}$ & 18041 & $10.872 \pm 0.0513^{\mathrm{Ef}}$ \\
\hline 10 & 6836 & $13.783 \pm 0.0635^{\mathrm{Ff}}$ & 7107 & $11.798 \pm 0.058^{\mathrm{Bc}}$ \\
\hline 11 & 6919 & $13.086 \pm 0.0615^{\mathrm{BDb}}$ & 6899 & $10.769 \pm 0.0554^{\mathrm{Ef}}$ \\
\hline 12 & 15295 & $13.312 \pm 0.0534^{\mathrm{Bg}}$ & 15284 & $11.412 \pm 0.0476^{\text {Fgh }}$ \\
\hline Calving Year & & $* *$ & & $* *$ \\
\hline 2001 & 28477 & $11.154 \pm 0.0278^{\mathrm{Aa}}$ & 28438 & $10.392 \pm 0.0251^{\mathrm{Aa}}$ \\
\hline 2002 & 18029 & $11.730 \pm 0.0312^{\mathrm{Bb}}$ & 18018 & $11.002 \pm 0.0284^{\mathrm{Bb}}$ \\
\hline 2003 & 18986 & $12.686 \pm 0.0280^{\mathrm{Cc}}$ & 18981 & $11.422 \pm 0.0251^{\mathrm{Cc}}$ \\
\hline 2004 & 15011 & $13.130 \pm 0.0293^{\mathrm{Dd}}$ & 15005 & $11.445 \pm 0.0264^{\mathrm{Cc}}$ \\
\hline 2005 & 15989 & $14.571 \pm 0.0278^{\mathrm{Ee}}$ & 15986 & $12.300 \pm 0.0251^{\mathrm{Dd}}$ \\
\hline 2006 & 24456 & $14.135 \pm 0.0227^{\mathrm{Ff}}$ & 24449 & $12.568 \pm 0.0205^{\mathrm{Ee}}$ \\
\hline 2007 & 16963 & $13.521 \pm 0.0271^{\mathrm{Gg}}$ & 16978 & $11.147 \pm 0.0244^{\mathrm{Ff}}$ \\
\hline 2008 & 15743 & $12.775 \pm 0.0278^{\mathrm{Cc}}$ & 15740 & $10.151 \pm 0.0250^{\mathrm{Gg}}$ \\
\hline 2009 & 13756 & $13.277 \pm 0.0307^{\mathrm{Dh}}$ & 13756 & $10.342 \pm 0.0278^{\mathrm{Aa}}$ \\
\hline 2010 & 5416 & $12.128 \pm 0.0478^{\mathrm{Hi}}$ & 5420 & $9.629 \pm 0.0431^{\mathrm{Hh}}$ \\
\hline Parity & & $* *$ & & $* *$ \\
\hline 1 & 57053 & $12.545 \pm 0.0183^{\mathrm{Aa}}$ & 57015 & $10.564 \pm 0.0165^{\mathrm{Aa}}$ \\
\hline 2 & 46462 & $13.111 \pm 0.0192^{\mathrm{Bb}}$ & 46462 & $11.105 \pm 0.0173^{\mathrm{Bb}}$ \\
\hline 3 & 29584 & $13.694 \pm 0.0231^{\mathrm{Cc}}$ & 29577 & $11.701 \pm 0.0208^{\mathrm{Cc}}$ \\
\hline 4 & 15418 & $12.842 \pm 0.0308^{\mathrm{Dd}}$ & 15409 & $10.996 \pm 0.0278^{\mathrm{Dd}}$ \\
\hline 5 & 24309 & $12.360 \pm 0.0234^{\mathrm{Ee}}$ & 24308 & $10.834 \pm 0.0211^{\mathrm{Ee}}$ \\
\hline Lactation Month & & $* *$ & & $* *$ \\
\hline 1 & 15092 & $15.407 \pm 0.0303^{\mathrm{Aa}}$ & 15092 & $13.720 \pm 0.0273^{\mathrm{Aa}}$ \\
\hline 2 & 15128 & $16.754 \pm 0.0303^{\mathrm{Bb}}$ & 15129 & $14.732 \pm 0.0273^{\mathrm{Bb}}$ \\
\hline 3 & 15175 & $16.290 \pm 0.0302^{\mathrm{Cc}}$ & 15176 & $14.175 \pm 0.0272^{\mathrm{Cc}}$ \\
\hline 4 & 15022 & $15.485 \pm 0.0305^{\mathrm{Aa}}$ & 15026 & $13.310 \pm 0.0274^{\mathrm{Dd}}$ \\
\hline 5 & 14664 & $14.656 \pm 0.0310^{\mathrm{Dd}}$ & 14660 & $12.403 \pm 0.0278^{\mathrm{Ee}}$ \\
\hline 6 & 14390 & $13.651 \pm 0.0314^{\mathrm{Ee}}$ & 14383 & $11.470 \pm 0.0283^{\mathrm{Ff}}$ \\
\hline 7 & 14023 & $12.770 \pm 0.0319^{\mathrm{Hf}}$ & 14021 & $10.770 \pm 0.0287^{\mathrm{Gg}}$ \\
\hline 8 & 13628 & $11.834 \pm 0.0322^{\mathrm{Gg}}$ & 13628 & $9.959 \pm 0.0290^{\mathrm{Hh}}$ \\
\hline 9 & 12808 & $10.754 \pm 0.0332^{\mathrm{Hh}}$ & 12805 & $9.055 \pm 0.0299^{\mathrm{li}}$ \\
\hline 10 & 10828 & $9.900 \pm 0.0352^{\mathrm{li}}$ & 10834 & $8.388 \pm 0.0318^{\mathrm{Jj}}$ \\
\hline 11 & 8974 & $9.283 \pm 0.0385^{\mathrm{jj}}$ & 8963 & $7.782 \pm 0.0348^{\mathrm{Kk}}$ \\
\hline 12 & 23094 & $8.143 \pm 0.0251^{\mathrm{Kk}}$ & 23054 & $6.713 \pm 0.0226^{\mathrm{Ll}}$ \\
\hline Milking month & & $* *$ & & $* *$ \\
\hline 1 & 13354 & $13.292 \pm 0.0500^{\mathrm{AEa}}$ & 13315 & $10.757 \pm 0.0493^{\text {ACEabi }}$ \\
\hline 2 & 12999 & $13.138 \pm 0.0569^{\mathrm{AEa}}$ & 12989 & $10.816 \pm 0.0508^{\text {ACEabi }}$ \\
\hline 3 & 15515 & $12.858 \pm 0.0558^{\mathrm{Bb}}$ & 15457 & $10.648 \pm 0.0496^{\text {AEai }}$ \\
\hline 4 & 15176 & $12.612 \pm 0.0551^{\mathrm{Cc}}$ & 15128 & $10.813 \pm 0.0492^{\mathrm{ACEbj}}$ \\
\hline 5 & 15402 & $12.663 \pm 0.0549^{\mathrm{BCbc}}$ & 15369 & $11.269 \pm 0.0489^{\text {BDcetg }}$ \\
\hline 6 & 14323 & $12.623 \pm 0.0558^{\mathrm{BCbc}}$ & 14304 & $11.453 \pm 0.0497^{\mathrm{Bdh}}$ \\
\hline 7 & 14798 & $12.457 \pm 0.0559^{\mathrm{Cc}}$ & 14758 & $11.482 \pm 0.0501^{\mathrm{Bcdh}}$ \\
\hline 8 & 15158 & $12.203 \pm 0.0554^{\mathrm{Dd}}$ & 15120 & $11.046 \pm 0.0492^{\mathrm{CDbe}}$ \\
\hline 9 & 14824 & $13.017 \pm 0.0549^{\mathrm{ABab}}$ & 15176 & $11.470 \pm 0.0469^{\mathrm{Bdf}}$ \\
\hline 10 & 15430 & $13.092 \pm 0.0535^{\mathrm{ABab}}$ & 15399 & $11.302 \pm 0.0477^{\mathrm{Bgh}}$ \\
\hline 11 & 13007 & $13.382 \pm 0.0550^{\mathrm{EFa}}$ & 12946 & $10.812 \pm 0.0496^{\mathrm{ACab}}$ \\
\hline 12 & 12840 & $13.590 \pm 0.0551^{\mathrm{Fe}}$ & 12810 & $10.610 \pm 0.0498^{\mathrm{Eij}}$ \\
\hline Calving Month x Lactation Month & & $* *$ & & $* *$ \\
\hline Lactation Month x Milking Month & & $* *$ & & $* *$ \\
\hline Overall & 172826 & $12.79 \pm 0.011$ & 172771 & $11.14 \pm 0.010$ \\
\hline
\end{tabular}




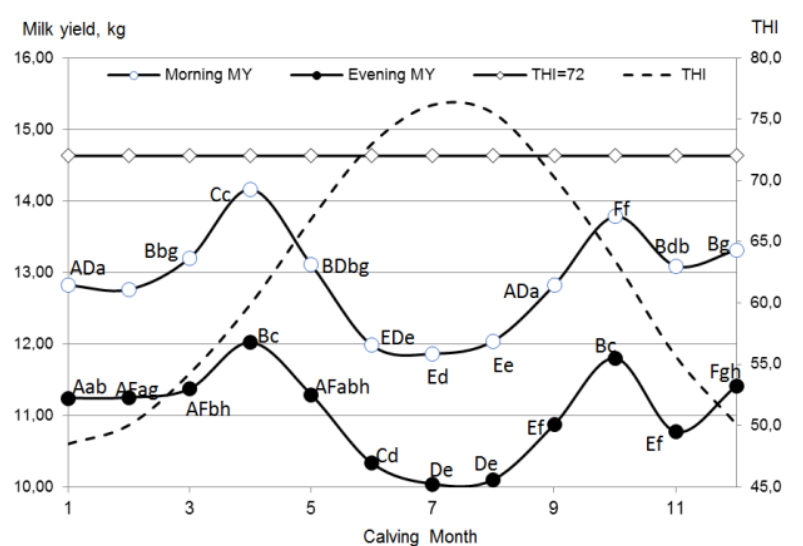

(a)

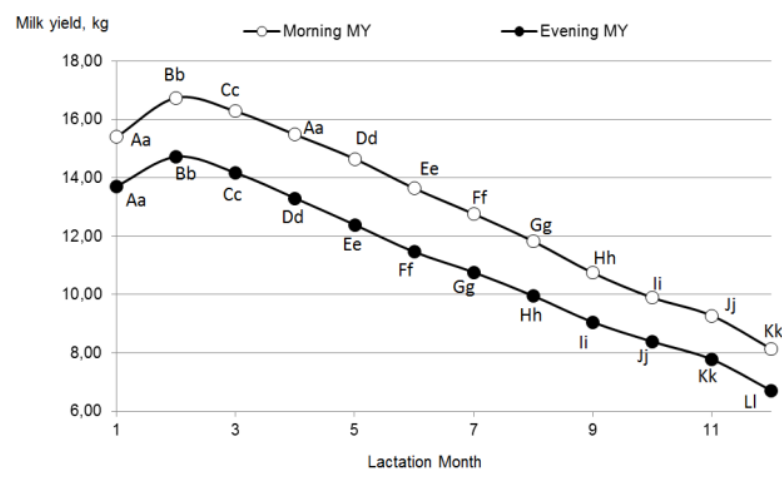

(c)

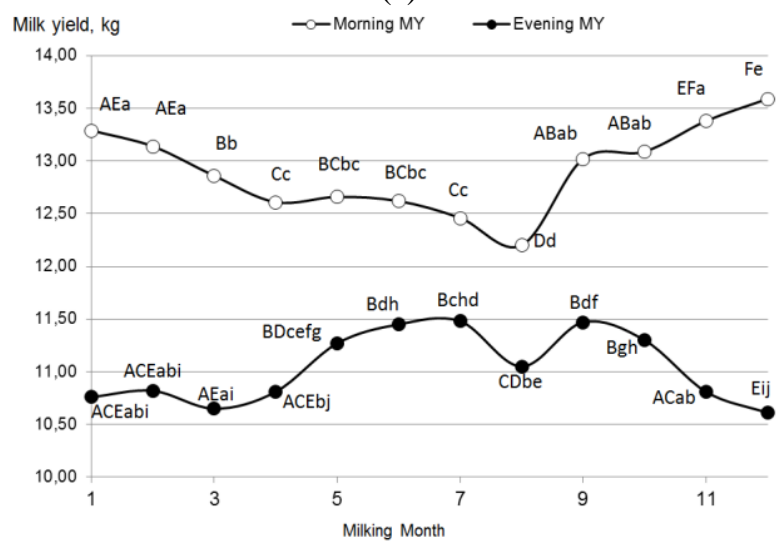

(e)

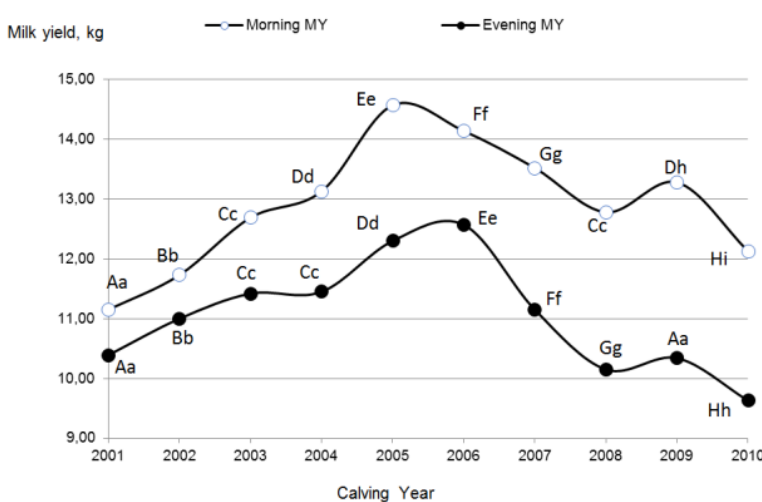

(b)

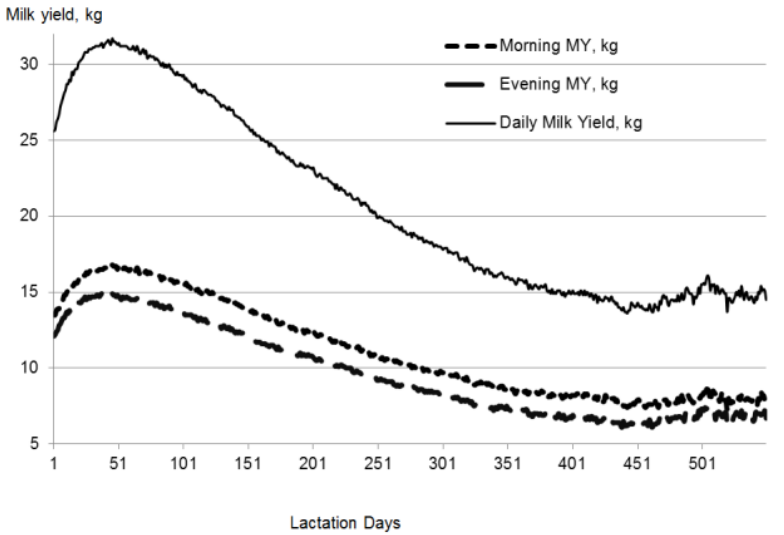

(d)

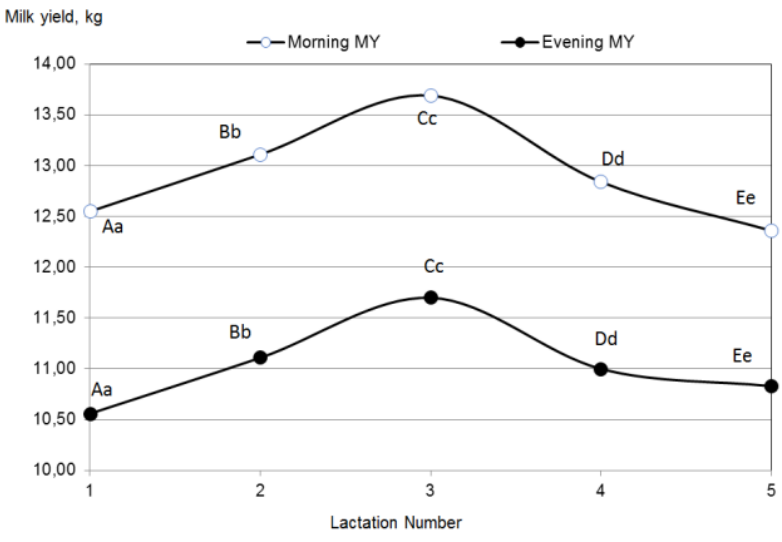

(f)

Figure 1 Morning and evening milk yield, a) monthly averages $(\mathrm{P}<0.01)$ and Temperature Humidity Index $(\mathrm{THI})$, b) calving year averages $(\mathrm{P}<0.01), \mathrm{c})$ lactation month averages $(\mathrm{P}<0.01)$, d) lactation days averages $(\mathrm{P}<0.01)$, e $)$ milking month averages $(\mathrm{P}<0.01)$ and $\mathrm{f})$ parity averages $(\mathrm{P}<0.01)$.

For calving year, the highest milk yield mean was determined for $2005(14.57 \pm 0.028 \mathrm{~kg})$ and the lowest mean for $2001(11.15 \pm 0.028 \mathrm{~kg})$ for MMY (Figure 1b). For EMY, the highest and the lowest means were determined for $2006(12.57 \pm 0.021 \mathrm{~kg})$ and for 2010 $(9.63 \pm 0.043 \mathrm{~kg})$, respectively. The differences between the milk yield means for all years were also found to be statistically significant for MMY $(\mathrm{P}<0.01)$. For EMY, except for the differences between 2003 and 2004 and between 2001 and 2009, all other differences were statistically significant $(\mathrm{P}<0.01)$.
As seen in Figure 1b, the milk yield means increased until 2005 for MMY and 2006 for EMY and then decreased. Increases in milk yield seen in the first few years could be attributed to the parities of the cows. This herd was established in 2001, and milk yield increased gradually in the following years depending on the increases in cow's parities. The older cows were then replaced with heifers, which might cause a reduction in milk yield in this herd. In addition, the reduction seen after 2005 in daily milk yield in this herd could be due to the reduction in the conditions of management and 
nutrition in this herd depending on the price instability of raw milk and increasing sources of Turkish dairy.

As seen in Table 1 and Figure 1c, with the $1.34 \mathrm{~kg}$ and $1.01 \mathrm{~kg}$ increases, the highest milk yield means were determined for the second lactation month in the morning $(16.75 \pm 0.030 \mathrm{~kg})$ and evening milkings $(14.73 \pm 0.027 \mathrm{~kg})$, respectively. The second month MMY was $2.02 \mathrm{~kg}$ higher than that of EMY. For every lactation month, the MMY means were higher than the EMY. Figure 1c shows that after the second month of lactation, the milk yield monthly means decreased gradually to the 12 month of lactation for both morning and evening milkings. The lowest means were detected at the $12^{\text {th }}$ month of lactation for both morning $(8.14 \pm 0.025 \mathrm{~kg})$ and evening $(6.71 \pm 0.023 \mathrm{~kg})$ milkings.

As seen in Figure 1d, the peak milk yield was determined on the 46th day of lactation $(16.8 \pm 0.019 \mathrm{~kg})$ for morning milking and at $14.9 \mathrm{~kg}$ for the 38th, 42th, 43th and 46th days for evening milking. For total daily milk yield, the highest mean was found on the 46th day of lactation $(31.7 \pm 0.013 \mathrm{~kg})$. For every lactation day, the MMY was also determined to be higher than those of the EMY (Figure 1d).

The peak day determined in this study is shorter than two other studies (Tekerli et al., 2000; Rekik et al., 2003), but longer than the result reported by Hansen et al. (2006). Similar peak days (range: 25-47 days) were also reported by Silvestre et al. (2009). The peak yield found in this study $(31.7 \pm 0.013 \mathrm{~kg})$ is higher than the results of two studies (Tekerli et al., 2000; Hansen et al., 2006), but lower than the results of two studies (Rekik et al., 2003; Silvestre et al., 2009).

As seen in Figure 1e, the MMY mean decreased from January to April and then very similar milk yield means were measured in April to July. After a small decrease in August, the MMY increased gradually from July to December. A nearly opposite pattern for EMY was noted. Milk yield mean increased from April to July, after a small decrease in August, the mean then decreased gradually from September to December. Between morning and evening milkings, higher milk yield differences were noted in the winter months, but the differences were small for summer months (Figure 1e). The seasonal differences detected in milk yield between milkings were mainly due to different milking intervals. Cows were milked late in the morning and early in the evening because of the longer night in the winter. Thus, the interval between morning and evening milking increased in the winter months. Figure 1e shows that for the morning milkings in August, the milk yield was $10.2 \%$ lower than in December. However, the evening milking yield in August was 7.6\% higher than in December.

For parity, the highest means for both milkings were determined for the $3^{\text {rd }}$ parity $(13.69 \pm 0.023 \mathrm{~kg}$ vs. $11.70 \pm 0.021 \mathrm{~kg}$ ) for this herd; the lowest mean was for the $5^{\text {th }}$ parity $(12.36 \pm 0.023 \mathrm{~kg})$ for MMY and the first parity $(10.56 \pm 0.017 \mathrm{~kg})$ for EMY. For both milkings, all parity differences were statistically significant for MMY and EMY ( $\mathrm{P}<0.01$; Figure 1f).

\section{Conclusions}

In this study, some important findings about the factors having effects on milking time milk yield in $\mathrm{RH}$ cows were determined. In summer, because of high THI seen in the region, the weather conditions become one of the significant factors reducing the milk yield of cows. The reduction is very obvious in cows calved in summer. Some significant findings also determined between the morning and evening milkings milk yield. Between the milkings, the milk yield differences were much higher in winter time because of longer interval at night depending on the daylight. For this herd and the herds in the region, taking precautions to protect the cows from heat stress especially for the cows who calved in summer and keeping the milking interval equal for whole year would help increasing the milk yield. In addition, it is advised that as an environmental factor, milking time needs to be put in to the statistical model especially evaluating the data from the herds in which unequal milking time is operated.

\section{References}

Banerjee D, Ashutosh. 2011. Effect of thermal exposure on diurnal rhythms of physiological parameters and feed, water intake in Tharparkar and Karan Fries heifers. Biological Rhythm Research. 42(1): 39-51.

Barash H, Silanikove N, Shamay A, Ezra E. 2001. Interrelationships among ambient temperature, day length, and milk yield in dairy cows under a Mediterranean climate. Journal of Dairy Science. 84: 2314-2320.

Bernabucci U, Lacetera N, Ronchi B, Nardone A. 2002. Effects of hot season on milk protein fractions in dairy cows. Animal Research. 51: 25-33.

Bertocchi L, Vitali A, Lacetera N, Nardone A, Variscoand G, Bernabucci U. 2014. Seasonal variations in the composition of Holstein cow's milk and temperature-humidity index relationship. Animal. 8(4): 667-674.

Bouraoui R, Lahmar M, Majdoub A, Djemali M, Belyea R. 2002. The relationship of temperature-humidity index with milk production of dairy cows in a Mediterranean climate. Animal Research. 51: 479-491

Gantner V, Mijić P, Kuterovac K, Solić D, Gantner R. 2011. Temperature-humidity index values and their significance on the daily production of dairy cattle. Mljekarstvo. 61(1):56-63.

Gürses M, Bayraktar M. 2012. Some Milk Production and Reproductive Traits of Holstein Cattle Raised in Different Regions of Turkey. Journal of the Faculty of Veterinary Medicine, Kafkas University. 18(2): 273-280

Hammond AC, Chase CC, Bowers EJ, Olson TA, Randel RD. 1998. Heat tolerance in Tuli, Senepol, Brahman sired F1 Angus heifers in Florida. J Anim Sci. 76: 1568-1577.

Hansen JV, Friggens NC, Højsgaardet S. 2006. The influence of breed and parity on milk yield, and milk yield acceleration curves. Livestock Science. 104: 53- 62

Kibler HH. 1964. Environmental physiology and shelter engineering. LXVII. Thermal effects of various temperaturehumidity combinations on Holstein cattle as measured by eight physiological responses. Res Bull Missouri Agric Exp Station, p. 862 .

Koc A. 2007. Daily milk yield, non-fat dry matter content and somatic cell count of Holstein-Friesian and Brown-Swiss cows. Acta Veterinaria (Beograd). 57(5-6): 523-535.

Koc A. 2008. Factors influencing daily yield, somatic cell count and non-fat dry matter content of milk. Indian Vet. J. 85:630-632. 
Koc A, Kizilkaya K. 2009. Factors influencing test day milk yield of Holstein-Friesian cows. Hayvansal Üretim. 50(1): 24-30.

Koc A. 2011. A study of the reproductive performance, milk yield, milk constituents, and somatic cell count of Holstein-Friesian ad Montbeliarde cows. Turk. J. Vet. Anim. Sci. 35(5): 295-302.

Koc A. 2012. Short Communication. Effects of some environmental factors and extended calving interval on milk yield of Red Holstein cows. Spanish J. of Agricultural Research. 10(3): 717721.

Koç A. 2015. Effects of Somatic Cell Count and Various Environmental Factors on Milk Yield and Foremilk Constituents of Red-Holstein Cows. Journal of Agricultural Sciences. 21(3): 439-447

Linvill DE Pardue FE. 1992. Heat stress and milk production in the South Carolina coastal plains. Journal of Dairy Science. 75: 2598-2604

M'hamdi N, Bouallegue M, Frouja S, Ressaissi Y, Kaur-Brar S, Hamouda MB. 2012. Effects of Environmental Factors on Milk Yield, Lactation Length and Dry Period in Tunisian Holstein Cows, Milk Production - An Up-to-Date Overview of Animal Nutrition, Management and Health, Prof. Narongsak Chaiyabutr (Ed.), ISBN: 978-953-51-0765-1, InTech, http://dx.doi.org/10.5772/5080
Ravagnolo O, Misztal I. 2000. Genetic component of heat stress in dairy cattle, parameter estimation. Journal of Dairy Science. 83: 2126-2130.

Rekik B, Ben Gara A, Ben Hamouda M, Hammami H. 2003. Fitting lactation curves of dairy cattle in different types of herds in Tunisia. Livestock Production Science. 83: 309-315

Şahin A, Ulutaş Z. 2011. Some environmental factors affecting the milk yield and reproductive traits of Holstein cattle raised at Tahirova State Farm. Anadolu J Agr Sci. 26(2):156-168

SAS, Statistical Analysis System for Windows (Release 8.2). 1999. SAS Institute Inc., Raleigh, North Carolina, USA.

Sivestre AM, Martins AM, Santos VA, Ginja MM, Colaço JA. 2009. Lactation curves for milk, fat and protein in dairy cows: A full approach. Livestock Science. 122: 308-313

Tekerli M, Akıncı Z, Doğan I, Akcan A. 2000. Factors Affecting the Shape of Lactation Curves of Holstein Cows from the Balikesir Province of Turkey. Journal of Dairy Science. 83:1381-1386

Yilmaz H, Koc A. 2013. A research on milk yield, persistency, milk constituents and somatic cell count of Red Holstein cows raised under Mediterranean climatic conditions. Bulgarian Journal of Agricultural Science. 19(6):1401-1407. 